\title{
CRIMINAL LEGAL DEFINITION OF THE CONCEPT OF TORTURE AND DIFFERENTIAL DISTINCTION OF TORTURE FROM RELATED CRIMES
}

\author{
Alla Radzivill ${ }^{1}$ \\ ${ }^{1}$ Postgraduate student, Kyiv University of Law of the National Academy of Sciences of Ukraine, assistant \\ judge of the Supreme Court, Kyiv, Ukraine, e-mail: alla.radzivill@gmail.com
}

\begin{abstract}
The article highlights the clarification and definition of criminal legal concept of torture, the study of peculiarities of this crime corpus delicti and its basic features, distinction from related categories; proposals regarding the improvement of provisions of the Criminal Code of Ukraine have been formulated. The purpose of writing this article is represented by the study and criminal legal analysis of torture (Article 127 of the Criminal Code of Ukraine), analysis of the main and qualified corpus delicti of torture under the Criminal Code of Ukraine; the identification of types, methods and ways of torture; the definition of the scientific concept of "torture" and related concepts; the determination of criteria for distinguishing the corpus delicti of torture from related crimes under the Criminal Code of Ukraine; the analysis of international legal acts aimed at protecting human rights and preventing torture and other cruel, inhuman or degrading treatment or punishment; the analysis of Ukrainian national legislation in terms of its compliance with international law in the field of protection of a person from encroachment on his/her life, health, honour and dignity, which represents torture. The methodological basis of the study is represented by a set of methods and techniques of scientific knowledge, both general and special: historical, functional analysis, system-structural, formal-logical, comparative-legal, formal-legal, generalization. The author concludes that the concept of "torture" is not clearly defined in national law, underlines the feasibility of developing a mechanism for criminal legal counteraction to torture in the context of international standards. Besides, the article highlights the norms and provisions of international-legal norms on the prevention of torture and analyzes the importance of European organizational legal mechanisms to prohibit torture.
\end{abstract}

Keywords: torture, inhuman treatment, abuse, crime, criminal liability, international experience, counteraction, court, corpus delicti, criminal law qualification, criminal code.

JEL Classification: I30, K14, K24, K40

Formulas: 0; fig.: 0; tabl.: 0; bibl.: 14

Introduction. The prohibition of torture is an imperative rule of international law and, as the European Court of Human Rights has consistently emphasized in its case-law, reflects one of the fundamental values of a democratic society. The guarantees of the human right to life and protection from ill-treatment or other inhuman treatment are enshrined in all major international documents, from the general principles of international law, international documents of customary law to international treaties at the universal and regional levels. To define the concept of "torture" it is necessary to outline the specific characteristics of this crime, to determine the main features of the corpus delicti of this crime and to make a clear distinction from related crimes.

Literature Review. The study is based on the results of law enforcement practice examination, comprehensive and systematic analysis of national research on combating torture, criminal law of Ukraine, as well as international normative-legal acts (including the European Convention for the Protection of Human Rights and Fundamental Freedoms of November 4, 1950, the European Convention for the 
Prevention of Torture and Inhuman or Degrading Treatment or Punishment of November 26, 1987), etc.

Aims. The purpose of writing this article is represented by the study and criminal legal analysis of torture (Article 127 of the Criminal Code of Ukraine), analysis of the main and qualified corpus delicti of torture under the Criminal Code of Ukraine; the identification of types, methods and ways of torture; the definition of the scientific concept of "torture" and related concepts; the determination of criteria for distinguishing the corpus delicti of torture from related crimes under the Criminal Code of Ukraine; the analysis of international legal acts aimed at protecting human rights and preventing torture and other cruel, inhuman or degrading treatment or punishment; the analysis of Ukrainian national legislation in terms of its compliance with international law in the field of protection of a person from encroachment on his/her life, health, honour and dignity, which represents torture.

Methods. The methodological basis of the study is represented by a set of methods and techniques of scientific knowledge, both general and special: historical, functional analysis, system-structural, formal-logical, comparative-legal, formallegal, generalization.

Results. Pursuant to the Constitution, an individual, his life and health, honour and dignity, inviolability and security shall be recognised in Ukraine as the highest social value; no one shall be subjected to torture, cruel, inhumane, or degrading treatment or punishment [1]. In this regard, it is important to determine the extent to which the bodies of inquiry, pre-trial investigation, prosecution and court comply with this constitutional provision in practice; what are the procedural guarantees, theoretical, legal and practical problems of exercising this right.

Indeed, our state has given its consent regarding the obligation to implement a number of international agreements, which in accordance with Art. 9 of the Constitution of Ukraine became a part of the national legislation of Ukraine, in particular the Convention for the Protection of Human Rights and Fundamental Freedoms of 1950 [2], the International Covenant on Civil and Political Rights of 16 December 1966 [3], the Convention against Torture and Other Cruel, Inhuman or Degrading Treatment or Punishment of 10 December 1984 [4], the European Convention for the Prevention of Torture and Inhuman or Degrading Treatment or Punishment of 26 November 1987 [5].

However, in Ukraine, within the legal system, the traditional attitude to human rights as a kind of "optional" element in the formation and functioning of the criminal justice system remains a problem. A similar attitude prevails in society as a whole, when any, even very severe measures are considered justified in the fight against crime. The high level of human rights violation is evidenced by the fact that Ukraine ranked third according to the number of appeals to the European Court of Human Rights. Unfortunately, this points not only to problematic issues in the activities of law enforcement agencies, but also to the fact that the injured parties cannot find adequate protection in court. Under these circumstances, it is especially important to form reliable theoretical and methodological foundations for the study of European experience, analysis of conditions that will promote the reformation of the system of 
combating against torture in Ukraine in accordance with European standards, to ensure the independence and efficiency of the judiciary, to improve the quality of judgments in accordance with European standards.

Given that the corpus delicti of the crime under investigation is relatively new in Ukrainian criminal law, in practice there are problems with the legal assessment of torture, with its distinction from related crimes. This makes it essential to study the applied law enforcement aspect of the fight against torture, which is important for law-enforcement bodies.

Scientific researches in the field of criminal law on liability for torture and related crimes have been carried out by a number of both domestic and foreign scholars (I. Bohatyriov, Ye. Bulavin, O. Dzhuzha, D. Dil, M. Donelli, M. Evans, V. Ilnytskyi, K. Katerynchuk, O. Kostenko, S. Liakhova, V. Stashys, V. Tatsii, M. Khavroniuk, A. Cherviatsova, etc.), however, after the implementation of reforms, criminal law needs to be improved, as well as the analysis of problems of legal regulation and the development of ways to solve them.

The criminal legal understanding of torture should not be confused with everyday, vital one, according to which strong and mental emotional stress can be included in the concept of torture, because the basis of criminal liability is represented by the commission of an act that contains all the elements of a crime under the Criminal Code. Incorrect or inaccurate qualification violates the principle of fairness in criminal law, and errors in qualification are usually made due to misunderstanding of the terminology applied by the legislator. One of the most common problems of torture qualification is represented by the imperfection of the disposition of the article.

Presently, scholars consider torture as a complex antisocial-legal phenomenon, which makes it almost impossible to accurately formulate a definition that would reveal its essence in the best way. Thus, in the scientific literature we find different interpretations of the concept of "torture". They can be conditionally reduced to: 1) those which draw attention to the right to protection from torture (bearing in mind the personal safety of an individual); 2) those which reflect "torture" as one of the stages of "inhumane" treatment of an individual (their contents follow from the case law of the European Court of Human Rights); 3) those which do not contain all the features of torture (e.g., intimidation, suffering, coercion, etc.) in their definitions; 4) those which, while emphasizing the peculiarities of torture, at the same time, contain erroneous features that contradict the existing practice [6]. This is fully correlated with the legal definition of torture and fits into the doctrine of criminal law science.

International legal acts contain the following definitions of "torture":

- torture means any act by which severe pain or suffering, whether physical or mental, is intentionally inflicted by or at the instigation of a public official on a person for such purposes as obtaining from him or a third person information or confession, punishing him for an act he has committed or is suspected of having committed, or intimidating him or other persons (UN Declaration on the Protection of All Persons from Being Subjected to Torture and Other Cruel, Inhuman or Degrading Treatment or Punishment, 9 December 1975) [7]; 
- torture means the deliberate, systematic or wanton infliction of physical or mental suffering by one or more persons acting alone or on the orders of any authority, to force another person to yield information, to make a confession, or for any other reason (WMA Declaration of Tokyo, 1 October 1975, "Guidelines for Physicians Concerning Torture and other Cruel, Inhuman or Degrading Treatment or Punishment in Relation to Detention and Imprisonment") [8];

- the term "torture" means any act by which severe pain or suffering, whether physical or mental, is intentionally inflicted on a person for such purposes as obtaining from him or a third person information or a confession, punishing him for an act he or a third person has committed or is suspected of having committed, or intimidating or coercing him or a third person, or for any reason based on discrimination of any kind, when such pain or suffering is inflicted by or at the instigation of or with the consent or acquiescence of a public official or other person acting in an official capacity (UN Convention against Torture and Other Cruel, Inhuman or Degrading Treatment or Punishment, 10 December 1980) [9];

- torture shall be understood to be any act intentionally performed whereby physical or mental pain or suffering is inflicted on a person for purposes of criminal investigation, as a means of intimidation, as personal punishment, as a preventive measure, as a penalty, or for any other purpose. (Inter-American Convention to Prevent and Punish Torture, Organization of American States, 9 December 1985) [10].

Despite certain peculiarities, all the above definitions, both national and international-legal, have common points in which the essence of the phenomenon of torture is revealed, namely:

- torture means physical and non-physical violence against a person;

- torture always means intentionally committed act, i.e. the person who applies it, intentionally violates criminal law;

- torture means actions that are committed for a specific illegal purpose;

- victim of torture is a person who found himself in a very specific situation associated with restraint of liberty and certain dependence on officials of certain public authorities;

- torture can be a one-time (situational) or a systemic offense [11].

The legislative definition of torture is noted in Article 127 of the Criminal Code of Ukraine, which is noted in Chapter II of the Special Part of the Criminal Code of Ukraine "Criminal Offences against Life and Health of a Person" and provides liability for wilful causing of severe physical pain or physical or mental suffering by way of battery, martyrizing or other violent actions for the purpose of inducing the victim or any other person to commit involuntary actions including receiving from $\mathrm{him} / \mathrm{her}$ or any other person information or confession, or for the purpose of punishing him/her or any other person for the actions committed by him/her or any other person or for committing of which he/she or any other person is suspected of, as well as for the purpose of intimidation and discrimination of him/her or other persons [12]. 
The main direct object of torture is human health, the obligatory additional object is represented by the honour, dignity and will of the person. The objective aspect of the crime is characterized by the presence of three mandatory features: the act, the consequence and the causal link between them. A socially dangerous act consists of dynamic actions expressed in inflicting battery, torture, and other violent acts. However, it should be noted that this crime can be committed in the form of inaction. A socially dangerous consequence is presented in the form of causing the victim severe physical pain or physical or mental suffering. As for the causal link between these actions and the consequences, it can be represented by: severe physical pain, physical or mental suffering resulting from the battery, martyrizing or other acts of violence. The subject of the crime provided for in Article 127 of the Criminal Code of Ukraine is a general one (a sane individual who has reached the age of 16 years). From the subjective aspect, torture is characterized as an intentional form of guilt, herewith the intent can be both direct and indirect. It should be noted that the obligatory feature of torture is the presence of a special purpose of the perpetrator to encourage the victim or another person to commit acts contrary to their will, including obtaining from him or another person information, testimony or confession, to punish for his actions, which he has committed or is suspected of committing, or intimidating him or others. It should be noted that the disposition of Article 127 of the Criminal Code of Ukraine does not provide for motivating a person to refrain from performing actions as a special purpose.

Thus, in particular, Part 2 of Article 126 of the Criminal Code of Ukraine provides for additional common elements of the corpus delicti: tortures covered by the concept of "martyrizing"; special purpose - intimidation of the victim or his relatives (Article 127 provides for intimidation of the victim or other persons).

Thus, the elements of torture and battery and torment will be identical, if the perpetrator inflicts severe physical pain by inflicting battery, torment or other acts of violence to the victim for the purpose of intimidation of him (or his relatives). This circumstance is inadmissible, especially if we take into account the fact that the sanctions of Part 1 of Article 127 and Part 2 of Article 126 of the Criminal Code of Ukraine differ in the types and amount of punishment. The solution to this problem is possible only at the legislative level by excluding the special purpose of "intimidation" from the disposition of Part 2 of Article 126 of the Criminal Code of Ukraine (the exclusion of this special purpose from the disposition of Article 127 would result in non-compliance with the requirements of the UN Convention against Torture) [13].

While delimitating similar crimes it is necessary to pay attention to Art. 189 of the Criminal Code of Ukraine. Thus, Part 3 of this article provides for criminal liability for extortion accompanied with violence dangerous to life and health of an individual. In the context of this article, violence covers the battery, including torment, torture, infliction of trivial injury resulting in a short-term health disorder or minor disability, moderate bodily injury or other acts of violence (i.e. an act provided for by an objective aspect of the torture). The consequence of such actions is severe physical pain or physical or mental suffering. The purpose of this article consists of 
the following: the illegal obtainment of another's property, the right to property or obtaining the commission of a property nature act by the victim; in essence it is an incentive to commit acts contrary to the will of the person. The purpose provided for by this article helps to separate the extortion from torture. In the case of extortion, there is an exclusively selfish motive, which cannot be said about torture, where there is no such a motive [14].

Conclusion. Given the general criminal law analysis of the crime under Art. 127 of the Criminal Code (torture), the following conclusions can be drawn:

1. The use of torture is a direct violation of constitutional norms, since such actions cause a person physical and mental suffering, which is contrary to the constitutional principles that operate within the rule of law state. In most cases, torture is associated with the restriction of liberty, and it should be noted that even in captivity, a person cannot be tortured, which is contrary to the principle of inviolability. Non-physical torture, which is very often associated with the threat of violence against family members of a person whose information is collected and used without the latter's consent, is also a violation of the constitutional norm, which entails liability. Very often torture is a means of influencing those who express their views regarding the violation of rights in detention centres, i.e. they point out the shortcomings of the system and therefore become victims of torture. In this case, the purpose of the violence is to oblige the person to remain silent about systemic offenses. Information obtained from a person through the use of torture belongs to evidence obtained illegally.

2. Torture has a high level of latency, so the problems associated with combating the type of crime under investigation are relevant. First of all, cases of torture do not always become known to the court, as victims do not apply to law enforcement bodies for the protection of their violated rights, do not believe that the perpetrators, often from the law enforcement agencies themselves, will be identified and punished, and the caused damage will be compensated. In some cases, the victim does not even realize that a crime has been committed against him or her because the perpetrators were law enforcement or other public officials and acted as if to achieve legitimate goals and to protect legitimate interests. This also includes the fear of revenge, harm to themselves and their relatives by those, whose actions are challenged.

3. The problem of timely and complete detection of the facts of such a crime commitment and ensuring the inevitability of punishment for it, which will promote the establishment of legality.

\section{References:}

1. Constitution of Ukraine [E-source] // Journal of the Verkhovna Rada of Ukraine (JVR). - 1996. - No. 30.

- p. 141. - Access mode: http://zakon5.rada.gov.ua/laws/show/254\%D0\%BA/96-\%D0\%B2\%D1\%80 [in Ukrainian]

2. Convention for the Protection of Human Rights and Fundamental Freedoms of 1950, First Protocol and Protocols Nos. 1, 4, 6, 7, 9, 10, 11 and 13 to the Convention (Rome, 4.XI. 1950) // Prof. legal comp. system "Infodisk: Legislation of Ukraine" [in Russian] 
3. International Covenant on Civil and Political Rights (the International Covenant has been ratified by the Decree of the Presidium of the Supreme Soviet of the Ukrainian Soviet Socialist Republic No. 2148-VIII (2148-08) of 19.10.73) [in Russian]

4. Convention against Torture and Other Cruel, Inhuman or Degrading Treatment or Punishment // Journal of the Supreme Soviet of the Ukrainian Soviet Socialist Republic - 1987. - No. 6, p.101 [in Russian]

5. European Convention for the Prevention of Torture and Inhuman or Degrading Treatment or Punishment of 26.11.1987. [E-source]. - Access mode: https://zakon.rada.gov.ua/laws/show/995_068\#Text [in Ukrainian]

6. O. Yaremko. Legislative Regulation of Criminal Liability for Torture in Ukraine / O. Yaremko // Scientific Information Bulletin. - 2013. - No. 8. - P. 176-181.]. [in Ukrainian]

7. On the Protection of All Persons from Being Subjected to Torture and Other Cruel, Inhuman or Degrading Treatment or Punishment: UN Declaration, 9 December 1975 [E-source] - Access mode: http://zakon3.rada.gov.ua/laws/show/995_084.] [in Russian]

8. Guidelines for Physicians Concerning Torture and other Cruel, Inhuman or Degrading Treatment or Punishment in Relation to Detention and Imprisonment: WMA Declaration of Tokyo, 1 October 1975 [Esource]. - Access mode: http://zakon3.rada.gov.ua/laws/show/990_011 [in Russian]

9. Against Torture and Other Cruel, Inhuman or Degrading Treatment or Punishment: UN Convention, 10 December 1980 [E-source]. - Access mode: http://zakon2.rada.gov.ua/laws/show/995_085 [in Ukrainian]

10.To Prevent and Punish Torture: Inter-American Convention of the Organization of American States, 9 December 1985 [E-source]. - Access mode: http://zakon2.rada.gov.ua/laws/show/995_068.] [in Ukrainian]

11.Viktor Filatov. «The Phenomenon of Torture: Constitutional and Legal Aspect». E-source. Access mode: http://pk.khpg.org/index.php?id=1487855321 [in Ukrainian]

12. Criminal Code of Ukraine: Law of Ukraine of 05.04.2001 No. 2341-III // Journal of the Verkhovna Rada of Ukraine. - 2001. - No. 25-26. - Art. 131 [in Ukrainian]

13.Yu Krychun. "The Problem of Distinguishing Torture from Some Related Crimes." Entrepreneurship, Economy and Law 5 (2017): 201-204 [in Ukrainian]

14.N. Maliarchuk. «Issues of Qualification and Distinguishing of Torture from Related Crimes» / N. Maliarchuk, A. Rozdilna // Journal of Eastern European Law. - 2018. - No. 58. - P. 103-108. [in Ukrainian] 